\title{
Menn i parforhold: arbeid for kjærligheten - innsats for likeverdighet?
}

Publisert i Sosiologisk Tidsskrift 2007; Vol. 15:337-352

Tove Thagaard, Universitetet i Oslo tove.thagaard@sosiologi.uio.no

Department of Sociology and Human Geography University of Oslo

P.O.Box 1096 Blindern

N-0317 OSLO Norway

Telephone: $\quad+4722855257$

Fax:

$+4722855253$

Internet: http://www.iss.uio.no 


\section{MENN I PARFORHOLD: ARBEID FOR KJÆELIGHETEN - INNSATS FOR LIKEVERDIGHET?}

Tove Thagaard

tove.thagaard@sosiologi.uio.no

\section{Men in couple relationships: working for love - a contribution to equality?}

This is a study of the significance of men's contributions to love within established relationships. The results indicate that the man works for love by showing care towards his partner and by reflecting over what his efforts mean to her. The man also works for love when the responsivity he expresses towards his partner is characterised by emotional expressivity and contributes to her feelings of being acknowledged and valued. Through working for love, the man contributes to strengthening equality between himself and the woman in a relationship in which both experience reciprocality in relation to their commitment to their love. In relationships in which it is the woman who is mostly responsible for fostering love, the man's contribution involves reproducing gendered power between man and woman. The empirical foundation for this article is a study comprising interviews with 10 urban middle-class heterosexual couples. These are relationships in which we can expect the man to contribute towards the responsibility for love. Theoretically, the article builds on perspectives that emphasize care and social responsivity as fundamental features of close relationships.

Keywords: Caring, Emotional expressivity, Reciprocality, Equality, Gendered power

\section{Innledning}

Kjærligheten i vår tid representerer motsetninger og utfordringer. Vår kultur preges av forventninger om sterke følelsesmessige opplevelser og om en varig emosjonell tilknytning som kan representere en forankring i en konfliktfylt verden (Beck og Beck-Gernsheim, 1995: 45). Forestillinger om det etablerte parforholdet representerer et hegemonisk ideal i vår kultur ifølge Gross (2005: 286), til tross for at hyppigheten av samlivsbrudd og skilsmisser ikke gir noen garanti for parforholdets varighet. Mot denne bakgrunnen kan vi forstå utviklingen av en modell av kjærlighet som fremhever betydningen av å innarbeide gjensidige forpliktelser i hvordan vi utformer kjærligheten. Denne modellen 
betegner Illouz (1997: 193) for «kjærlighet som arbeid». Modellen er karakterisert ved forventninger om at partene investerer i den følelsesmessige kvaliteten og arbeider med parforholdet.

Hvordan forholder menn og kvinner seg til forventninger om å arbeide for kjærligheten? En rekke studier viser at kvinnen bidrar mer enn mannen når det gjelder å satse på parforholdet (Jamieson, 1999: 483-488; Strazdins og Broom, 2004: 356-361; Rauer og Volling, 2005: 577-579). Kvinnen beskrives som den hovedansvarlige i relasjoner hvor følelser har en avgjørende betydning (Duncombe og Marsden, 1995: 150; Illouz, 1997: 206). Studier av menns innsats innenfor parforholdet fremhever at menn bidrar mer på det praktiske enn det følelsesmessige plan (Cohen, 1990: 62; Kaufman, 1994: 148-150; Kimmel, 2004: 223). Holter (1995: 126) stiller spørsmålet om menn har den kompetanse for å investere i parforholdet som kvinner etterspør. De fleste studier av hvordan kjærligheten er kjønnet, fremhever hva kvinner savner når det gjelder menns innsats (Duncombe og Marsden, 1999: 93-98). Studier som fremhever kvinnens merinnsats (Jamieson, 1999: 477; Haavind, 2000: 201-202; Duncombe og Marsden, 1995: 163-165), relaterer kvinners situasjon til maktforhold mellom mann og kvinne.

På bakgrunn av forskningsresultater som viser at kvinnen yter mer for kjærligheten enn mannen gjør, er det særlig viktig å studere hva mannen faktisk bidrar med. I denne artikkelen skal vi fremheve mannens bidrag til kjærligheten. Vi fokuserer på par innenfor etablerte samliv, som har varighet som en uttalt målsetting. Problemstillingen formuleres som to spørsmål. Det første er som følger: Hvilken betydning har menns innsats for kjærligheten innenfor etablerte parforhold?

For å utvikle en forståelse av betydningen av mannens bidrag, baserer vi analysen på en relasjonell tilnæerming. Det vil si at vi fokuserer på mannens innsats og kvinnens reaksjoner i forhold til ham, og hvordan kvinnen beskriver sitt bidrag og mannens reaksjoner i forhold til henne. Med utgangspunkt i denne tilnærmingen kan vi utdype problemstillingen med følgende spørsmål: Hvilken betydning har menns innsats for maktforhold i kjærligheten mellom mann og kvinne?

Vi skal analysere disse spørsmålene på grunnlag av intervjuer med ti par (samboende eller gifte) som representerer den urbane middelklasse. Vi kan forvente at par i denne sosiale kategorien er fortrolig med ideologien om å arbeide for kjærligheten og at det derfor er sannsynlig at også mennene møter forventninger om betydningen av å ta vare på kjærligheten. I forhold til disse betraktninger, er utvalget hensiktsmessig for å studere mannens innsats. 


\section{Teoretisk bakgrunn}

Kjærligheten i parforhold kommer til uttrykk i hvordan partene bidrar og samhandler med hverandre. Vi skal fokusere på sider ved samhandlingen som fanges opp av begrepene omsorg og sosial responsivitet. Disse begrepene er sentrale i analyser av kjærlighet. Omsorg har referanse til hva partene gjør i forhold til hverandre (Jamieson, 1998: 158-162). Sosial responsivitet har referanse til hvordan partene forholder seg til hverandre ved å gi gjensvar i forhold til hverandres bidrag (Asplund, 1987: 11-25). Omsorg og sosial responsivitet er ikke gjensidig utelukkende begreper. Å vise omsorg kan også innebære en respons overfor den andre. I denne artikkelen foretar vi et analytisk skille mellom disse begrepene. Vi knytter omsorg til innsats på det praktiske plan, og sosial responsivitet til kommunikasjon mellom partene.

\section{Omsorg}

Jamieson (1998: 160) fremhever hvordan idealet om at kjærligheten er basert på gjensidig åpne samtaler tar oppmerksomheten bort fra hvordan kjærlighet $\mathrm{i}$ dagliglivet handler om hva partene gjør for og med hverandre. Med begrepet "stille intimitet" retter Jamieson (1998: 8) søkelyset mot betydningen av å fokusere på hvordan partene viser hverandre omsorg gjennom praktisk handling i hverdagen. Vi fokuserer på omsorg med referanse til hva Wærness (1999: 111) betegner som trinn to i etikken om omsorg, som både innebærer å erkjenne et omsorgsbehov og å ta ansvar for hvordan behovet bør dekkes. Den mening begge parter tillegger handlinger har betydning for om handlingene oppfattes som omsorg. Goffmans (1974: 21-39) rammeteori kan bidra til å belyse hvordan partene utvikler en felles definisjon av handlingers betydning slik at den enes budskap om omsorg også oppfattes slik av den andre.

Flere studier viser at måter å uttrykke omsorg på representerer et kjønnet mønster. Menn kontrollerer følelser og bidrar i mindre grad enn kvinner til å ta vare på relasjonen, skriver Kaufman (1994: 148-150). Menn møter utfordringer i parforholdet gjennom praktisk handling, ifølge Cohen (1990: 62). Kimmel (2004: 223) hevder at menn har en instrumentell tilnærming til kjærlighet. Kvinner bidrar mer på det emosjonelle plan ved at de investerer mer i at partneren skal ha det bra enn mannen gjør, hevder Strazdins og Broom (2004: 357). Bittman og Lovejoy (1993: 315) beskriver et tilsvarende mønster i resultatene fra sin studie. Holmes (2004: 195) finner at kvinner bidrar mer med omsorg for partneren selv om parene ikke bor sammen og derfor ikke deler daglige oppgaver. 


\section{Sosial responsivitet}

Asplund (1987: 11-12) fremhever hvordan "sosial responsivitet» har en grunnleggende betydning i menneskelig samhandling. Sosial responsivitet innebærer at vi gir hverandre tilbakemeldinger på hvordan vi ser og hører hverandre. Teorien har referanse til situasjoner hvor samhandlingen er preget av spontanitet og umiddelbarhet. Skatvedt (2006: 53) utdyper teorien om sosial responsivitet ved å fokusere på situasjoner hvor partene formidler at de berører og berøres av hverandre. Motsetningen til "sosial responsivitet» er ifølge Asplund (ibid: 149) fravær av respons, det vil si at den ene personen ikke får gjensvar fra den andre på hva hun eller han bidrar med.

Teorien om sosial responsivitet gir et utgangspunkt for å analysere kommunikasjonen i parforhold. Sosial responsivitet innebærer både gjensvar som omhandler det saklige innhold i kommunikasjonen og gjensvar som uttrykker følelsesmessige reaksjoner i forhold til innholdet i samtalen og i forhold til relasjonen mellom partene. Samtaler preges både av en saksorientert og en emosjonell utveksling.

Det er først og fremst den emosjonelle utvekslingen som gir assosiasjoner til det umiddelbare og spontane ved den sosiale responsiviteten. De følelsesmessige reaksjonene formidles non-verbalt, ved kroppsspråk, tonefall og stemmeleie. Bråten (2004: 132) beskriver hvordan et "følelsesmessig spontant system er aktivt med under frembringing og reaksjon på en meddelelse ansikt til ansikt». Bråten (2004: 131) fremhever hvordan saksnivået og det emosjonelle nivået inngår i et samspill, hvor de emosjonelle understrømmer «ledsager, understreker eller motsier det vi uttaler». Betydningen av sosial responsivitet har referanse til samspillet mellom disse to nivåer i kommunikasjonen.

Menns forhold til de emosjonelle sider ved kommunikasjon gir en bakgrunn for å forstå utfordringer som beskrives i studier av menn og kvinner i parforhold. Kaufman (1994: 148-49) beskriver hvordan menn holder følelsesmessige opplevelser tilbake og derfor er mer reserverte i nære relasjoner. Flere studier dokumenter at kvinner mener at menn gir for lite uttrykk for emosjonelle reaksjoner (Thompson og Walker, 1989: 846; Jamieson, 1998: 146; Dempsey, 2002: 103). Kvinner savner en respons fra mannen som gir budskap om at mannen verdsetter og anerkjenner dem (Duncombe og Marsden, 1999: 9597). Rauer og Volling (2005: 578) hevder at kvinner er mer emosjonelt ekspressive enn menn og at dette har en avgjørende betydning for tilfredshet med parforholdet. Hochschild (2003: 95) beskriver hvordan kvinner arbeider med sine følelsesmessige reaksjoner for å uttrykke følelser som de tror forventes av dem i parforholdet. 


\section{Makt}

Forskningsresultater som fremhever hvordan kvinnen bidrar mer enn mannen til å ta vare på kjæerligheten, tolkes i mange studier som uttrykk for maktforhold mellom mann og kvinne. Jamieson (1999: 477) fremhever hvordan en kjønnet ulikeverdighet på andre områder i samfunnet preger parforholdet. Maktforholdet mellom menn og kvinner er spesielt fremtredende i intimitetssfæren, skriver Duncombe og Marsden (1995: 163-165). Dette er et uttrykk for hva Bourdieu (1996: 38) betegner som "skjult makt». Verken mannen eller kvinnen er nødvendigvis klar over at samspillet mellom dem preges av makt.

Jónasdottir (1991: 104) hevder at maktforhold mellom mannen og kvinnen innebæerer at kvinner gir mer enn de får tilbake. Holmberg (1995: 191-193) fremhever at mannens dominerende posisjon i parforholdet innebæerer at han ikke behøver å utforske den andres følelser på samme måte som kvinnen. Haavind (2000: 201) betegner dette som at kvinnen relativt sett er underordnet mannen. Hun skriver at mannen kan vare som han er, mens kvinnen arbeider med å endre seg slik at hun kan elske mannen slik han er. Røthing (2004: 106115) beskriver strategier for hvordan tradisjonell mannlig overordning kan opprettholdes i forhandlinger hos par som har en oppfatning av at parforholdet er likestilt.

På den annen side fremhever Giddens (1994: 56-69) i sin analyse av intimitetens forandring at moderne parforhold utvikler seg i retning av likeverdighet. Med begrepet "rene relasjoner" fremhever Giddens (1994: 63) at det er den følelsesmessige kvaliteten, uavhengig av ytre rammer, som representerer grunnlaget for parforholdet. Empiriske studier som gjenspeiler Giddens' perspektiv viser at par som representerer gjensidig åpenhet er mer tilfredse med parforholdet enn par som representerer et mer kjønnet mønster (Gross og Simmons, 2002: 547-48). Thagaard (2005: 193-197) har vist at par forstår sin relasjon som et gjensidig prosjekt når begge parter prioriterer den andre og parforholdet.

Spenningsforholdet mellom på den ene side likeverd mellom partene og på den annen side et kjønnet maktforhold representerer et utgangspunkt for tolkningen av resultatene. Vi fokuserer på sammenhengen mellom mannens og kvinnens bidrag i forhold til omsorg og responsivitet på den ene side, og maktforhold mellom mann og kvinne på den annen side. Maktdimensjonen har likeverdighet og kjønnet makt som ytterpunkter. Begrepet kjønnet makt har referanse til situasjoner hvor mannen har mest innflytelse.

Forståelsen av makt i denne artikkelen er forankret i et perspektiv hvor makt ikke anses som en gitt størrelse, men hvor maktforhold ses som en prosess, hvor makt skapes, forsterkes eller modereres gjennom den innsats hver av partene bidrar med innenfor kjæerligheten. På bakgrunn av studier som anser 
kvinners merarbeid innenfor kjærlighet som uttrykk for kjønnet makt, retter vi hovedfokus mot betydningen av mannens innsats. Med utgangspunkt i perspektiver på makt, studerer vi hvordan forholdet mellom mannens og kvinnens innsats i forhold til omsorg og responsivitet gir grunnlag for tolkninger av henholdsvis likeverdighet og kjønnet makt.

\section{Data og metoder}

Data er basert på intervjuer med ti heteroseksuelle par i Oslo-området. De er etablert i parforhold som de anser som varige. Syv av parene er gift, tre av dem er samboende. Fire av parene har små barn. Deltakernes alder varierer fra 26 til 36 år. Deltakerne representerer følgende variasjoner i typer av yrker: økonomisk rådgivning, forskning, utredning, reklame, media, musikk, juridisk virksomhet, informasjonsteknologi, konsulentvirksomhet, administrativ ledelse, prosjektledelse og design. Alt i alt kan vi klassifisere deltakerne som representanter for den urbane middelklasse.

Parene ble rekruttert via bekjentskaper innenfor ulike yrkesmiljøer. Innenfor de ulike miljøene hadde vi kontakter som kjente noen som var villig til å delta. Ved denne fremgangsmåten etablerte vi deltakernes tillit til prosjektet, samtidig som vi unngikk å intervjue personer vi kjente fra før. De som ble spurt om å delta i prosjektet, fikk grundig informasjon på forhånd slik at de kunne ta stilling til om de ville delta eller ikke. Intervjuene var åpne og ustrukturerte. Alle deltakerne fikk de samme spørsmålene, men rekkefølgen av spørsmålene ble tilpasset det enkelte intervju.

Deltakerne ble intervjuet hver for seg, slik at vi fikk informasjon både om mannens og kvinnens oppfatninger av utfordringer i samlivet. ^ intervjue kvinnen og mannen hver for seg innebærer spesielle utfordringer når det gjelder å etablere tillit. Deltakerne må kunne føle seg trygge på at vi ikke røpet synspunkter fra den første personen når vi intervjuet den andre. Vi tok særlig hensyn til å etablere en tillitsfull atmosfæere, fordi vi antok at deltakerne trolig ikke ville uttrykke sine synspunkter på relasjonen hvis de ikke opplevde tilstrekkelig fortrolighet til intervjueren.

Fordelen med å intervjue kvinnen og mannen hver for seg er at slike data gir grunnlag for en relasjonelt orientert analyse. Vi får informasjon om hvordan partene beskriver sin egen innsats, hvordan de opplever partneres reaksjon på sin innsats og hvordan de oppfatter partnerens bidrag. Intervjuer med paret sammen vil trolig gi utrykk for en mer felles forståelse av parforholdet enn vi får ved å intervjue paret hver for seg.

Deltakelse i intervjuundersøkelser er preget av en selvseleksjon i den forstand at de som er villige til å delta, kan representere holdninger som har spesi- 
ell betydning for undersøkelsen. De vi har intervjuet gir uttrykk for et reflektert forhold til sitt samliv og en tydelig interesse for å snakke om kjærlighet. Vi kan også anta at de som er villige til å bli intervjuet, er mer fornøyde med parforholdet sitt enn mange andre. Disse seleksjonsmekanismene representerer imidlertid ingen hindring for analyse av hvordan mannen og kvinnen bidrar til kjærligheten i parforholdet.

I analysen av materialet har vi tatt utgangspunkt i mannens svar på spørsmål som omhandler omsorg og responsivitet, og vi vurderer forholdet mellom mannens og kvinnens svar på de samme spørsmålene. Følgende spørsmål representerer grunnlaget for analyser av omsorg og responsivitet: Hvordan synes du det er viktig å være som partner? Hvordan synes du det er viktig å bidra for å ta vare på kjærligheten? Hvordan viser du omsorg? Hvordan viser din partner omsorg? Hvordan viser du at du er glad i ham/henne? Hvordan viser din partner at hun/han er glad i deg? I hvilke situasjoner opplever du nærhet til din partner? Hvordan fungerer samtalene mellom dere? Kan du snakke med din partner om temaer som er viktige for deg og som du forbinder med fortrolighet? Hva tror du hun/han kan snakke med deg om? Er du flink til å lytte? Synes du at din partner er flink til å lytte?

Resultatene av analyser av alle parene fremstilles ved en presentasjon av fire utvalgte par som representerer kontraster i forhold til de forskningsspørsmål vi studerer. Disse parene er valgt ut fordi de representerer typiske mønstere i materialet. I to av parene fremhever begge parter mannens bidrag til å ta vare på kjærligheten. Johan og Eva beskriver hvordan mannen viser omsorg i forhold til partneren. Henrik og Camilla fremhever hvordan mannen gir uttrykk for en emosjonelt forankret responsivitet i kommunikasjon med partneren. De to andre parene karakteriseres ved mønstre som representerer en motsetning til de to foregående. Morten og Stina fremhever begge begrensninger ved hvordan mannen gir uttrykk for omsorg. Tor og Eli fremhever konflikter i kommunikasjonen mellom dem, og Eli legger vekt på at hun får lite respons gjennom samtaler med mannen.

\section{Menns omsorgsinnsats i parforholdet}

Vi skal studere betydningen av hvordan mannen gir uttrykk for omsorg og betydningen av partnerens omsorg i forhold til ham. Vi skal særlig legge vekt på hvordan mannen reflekterer over sin innsats for relasjonen og hva som bidrar til at hans handlinger enten beskrives som omsorg eller mangel på omsorg av partneren. 


\section{Reflektert omsorg: om å sette seg inn i den andres perspektiv}

Johan gir uttrykk for omsorgsverdier når han fremhever at han synes det er viktig å gjøre en innsats for å glede den andre. Han reflekterer over sin egen innsats og gir på denne måten uttrykk for at han prøver å sette seg inn i hva som er viktig for Eva. Han forteller at han orienterer seg i samlivsstoff i aviser og magasiner, og han mener at han har lært av dette at veien til en kvinnes hjerte går ved å gjøre noe for den andre: «Jeg arbeider med å skjerpe meg og skjønne at jeg må tenke på at den andre personen faktisk er en annen person, og ikke en del av seg selv. Selv om det kan føles slik. Det er viktig med en innsats for å opprettholde gnisten".

Når Johan reflekterer over hva han kan gjøre i forhold til partneren, gir han uttrykk for at han tenker på hva som er viktig for henne: «Hun er mye mer vant til å rydde enn jeg. Så når jeg skal glede henne litt, så ser jeg meg litt rundt her og så rydder jeg. Det synes hun er bra.» Den betydning Johans innsats har for Eva, er avhengig av at hun oppfatter hva han prøver å formidle med sin innsats. Evas utsagn tyder på at hun deler den forståelse Johan har: «Han er flink til å vise omsorg, jeg tror han er flinkere enn meg. Når jeg kommer sent hjem, lager han middagen. Og noen ganger rydder han.»

Som Goffman (1974: 21-39) fremhever i sin rammeteori, innebærer utviklingen av en felles forståelse at begge parter definerer situasjonen på samme måte. Eva gir uttrykk for at hun forstår situasjonen på samme måte som Johan: «Han rydder fordi han vet at når jeg kommer hjem, så vil jeg rydde, og da har han gjort det for meg». Med dette utsagnet fremhever hun at hun forstår at han ønsker å gjøre en innsats for henne. Andre studier (Thompson og Walker, 1989: 847; Kimmel, 2004: 225) viser at et resultat av at par ikke har en felles forståelse av de situasjoner hvor mannen bidrar, er at kvinnen ikke oppfatter mannens bidrag som uttrykk for en kjærlighetshandling.

Den felles forståelsen dette paret gir uttrykk for, vises også ved hvordan Johan vurderer Evas bidrag. Han setter pris på den omsorg Eva viser i forhold til ham, fordi han synes at hun forstår hva han trenger: "Hvis jeg er sliten, så får jeg hvile. Jeg kan slappe av, og hun ordner det som trengs». Den omtanke de viser for hverandre kan fanges opp med Bråtens (2000: 71-82) perspektiv på at altersentrisk deltakelse i andres aktiviteter er grunnlag for både å gi og å gjengjelde omsorg.

Den praktiske tilnærmingen til omsorg som Johan gir uttrykk for, reflekterer et mønster fra andre studier hvor mannen bidrar til kjærligheten gjennom praktisk innsats (Kimmel, 2004: 226). Men Johans innsats overskrider det praktiske plan, fordi han også reflekterer over betydningen av det han gjør i forhold til partneren. Den omtanke Johan viser når han vurderer konsekvensene av sin innsats i forhold til Eva, innebærer at han tar ansvar for den følel- 
sesmessige kontakten mellom dem. Dette ansvaret kommer også til uttrykk når det gjelder å håndtere utfordringer i parforholdet. Det er like ofte Johan som Eva som tar initiativ til å ta opp ting som er vanskelige i forholdet mellom dem.

Den gjensidighet de begge uttrykker i beskrivelsene av hvordan partneren viser omtanke og forstår hva de trenger, gir grunnlag for en konklusjon om likeverdighet. Likeverdigheten er basert på at begge tar ansvar for å ta vare på kjærligheten i parforholdet. Johan bidrar til likeverdighet gjennom å dele ansvaret for å ta vare på kjærligheten med sin partner. Den gjensidighet i ansvaret for relasjonen som dette paret representerer, er særlig interessant i forhold til en tendens som er dokumentert i andre studier til at kvinnen har hovedansvaret for å ta vare på parforholdet (Illouz, 1997: 206; Duncombe og Marsden, 1999: 206; Strazdins og Broom, 2004: 356-361).

\section{Når omtanke mangler: omtankens betydning for omsorg}

Vi kan betrakte Bråtens (2000: 71-82) begrep om "altersentrisk deltakelse» som et nøkkelbegrep i forståelsen av hvordan handlinger som den ene utfører oppleves som omsorg av den andre. Hos de par hvor kvinnen ikke er fornøyd med måten mannen viser omsorg på, gir ikke mannen uttrykk for å sette seg inn i den andres perspektiv på samme måte som Johan.

Vi skal utdype dette i analysen av paret Morten og Stina. Morten forteller om seg selv at han ikke er spesielt flink til å vise omsorg. Men «hvis det virkelig er noe, da gjør jeg som hun sier.» Han vet at hun savner at han yter litt ekstra. Dette har han planer om å følge opp, men «det har en tendens til å ikke bli noe av». Hans innsats er i hovedsak basert på hva han synes er greit å gjøre og i mindre grad på omtanke for Stina.

Stina deler Mortens oppfatning av at han ikke er særlig flink til å vise omsorg. Hun beskriver at hun enkelte ganger opplever at han viser omtanke for henne på en måte hun savner i dagliglivet. Det er situasjoner «hvor han gjør små ting som viser at han forstår hvordan jeg har det». Stort sett er Mortens innsats basert på at Stina ber ham om å hjelpe til, og da gjør han det. Hun savner at han viser mer omtanke for henne, slik at hun ikke behøvde å be ham om å hjelpe til. Morten er fornøyd med måten Stina viser omsorg på, fordi han synes at hun avlaster ham når han trenger det. Men Stina synes ikke at han bidrar på en tilsvarende måte overfor henne.

Karakteristisk for dette paret er at begge parter beskriver kvinnen som den primære omsorgspersonen. Både Morten og Stina fremhever at hun viser mer omtanke for partneren enn han gjør overfor henne. Den oppfatning de begge deler om at kvinnen bidrar mest, og at hun i tillegg er lite fornøyd med mannens innsats, gir grunnlag for en konklusjon om kjønnet makt. Kjønnet makt er her basert på "prinsippet om den minste interesse» (Engelstad, 1999: 22). 
Mannen gir uttrykk for mindre interesse enn kvinnen med hensyn til å investere i parforholdet. Konsekvensen av dette er at kvinnen har hovedansvaret for å ta vare på kjærligheten. Duncombe og Marsden (1995: 165) hevder at selv når mannen hjelper til, er kvinnen ansvarlig for at han gjennomfører de handlinger han har som intensjon å bidra med.

«Prinsippet om den minste interesse» kommer også til utrykk når det gjelder ansvar for å håndtere problemer i parforholdet. Stina tar oftest initiativ til å ta opp konflikter når det er uoverensstemmelser i forholdet mellom dem. Det ansvar Stina har for å ta vare på kjærligheten, kan forstås i lys av Holmbergs (1995: 189-191) perspektiv på kvinnens situasjon i parforholdet. Holmberg hevder at kvinnen må bidra med en relativt større innlevelse i mannens situasjon og tilpasning til ham enn hennes mann gjør overfor henne.

\section{Menns bidrag i forhold til sosial responsivitet}

Med utgangspunkt i teorien om sosial responsivitet skal vi studere hvordan menn gir uttrykk for emosjonell ekspressivitet i kommunikasjon med partneren. Vi fokuserer på samtaler hvor mannen setter ord på de følelser han har overfor partneren og på samtaler om hverdagslige temaer hvor mannen uttrykker emosjonell ekspressivitet som ledsager det saklige innholdet i det han sier. Vi retter hovedfokus mot mannens bidrag og den betydning dette har for hans kvinnelige partner. Spørsmålet om gjensidighet innebærer at vi også studerer kvinnens bidrag og den betydning dette har for mannen.

\section{Kommunikasjon preget av emosjonell ekspressivitet}

Henrik og Camilla fremhever begge at kommunikasjonen mellom dem er et sæerpreg ved parforholdet. De forteller at lange og gode samtaler er det viktigste grunnlaget for nærhet mellom dem. Næerheten er basert på hva Jamieson (1998: 1) betegner for "disclosing intimacy", det vil si at begge parter er åpne om tanker og følelser når de snakker sammen. Denne åpenheten kommer til uttrykk ved at de begge er opptatt av å sette ord på de følelser de har for hverandre og i måten de snakker om ting på i situasjoner hvor begge synes det er særlig viktig å få respons fra partneren.

Henrik fremhever hvordan han utrykker de følelsene han har for Camilla: «Jeg forteller henne ofte at jeg er glad i henne. Jeg sier det til henne så mye jeg kan.» Gjennom å sette ord på følelsene sine, bekrefter han at han ser og verdsetter henne. Camillas reaksjon viser hva dette betyr for henne: "Han sier ofte at han er stolt av meg og glad i meg. Da føler jeg meg veldig nær ham». Henrik bidrar til å styrke den følelsesmessige kontakten mellom dem når han snakker åpent om sine følelser. Camilla forteller at hun er tilsvarende åpen om sine 
følelser for ham. Henrik gir uttrykk for emosjonell ekspressivitet når han setter ord på de følelser han har overfor Camilla som bidrar til at hun opplever at hun blir verdsatt og bekreftet av ham.

Utfordringer når det gjelder mannens responsivitet er spesielt relevant $\mathrm{i}$ samtaler hvor kvinnen tar opp temaer hvor det er særlig viktig for henne å få respons fra partneren. Henrik forteller at de ofte har samtaler om kvelden «hvor vi snakker om hvordan vi har det og hva som har skjedd i løpet av dagen». Han gir uttrykk for at han både er interessert i det Camilla forteller og i å etablere en nær kontakt med henne: «Hun er så utrolig engasjert, og da kan jeg være med på det, så jeg føler at jeg er veldig nær henne. Hun deler veldig mye av seg selv med meg».

Henrik gir uttrykk for at han gir Camilla tilbakemeldinger som både handler om at han er interessert i det hun forteller og samtidig formidler et følelsesmessig engasjement i forhold til henne. Camillas reaksjon på disse samtalene viser at hun opplever Henriks responsivitet på denne måten. Hun sier at han gir henne respons i forhold til innholdet i det hun forteller, og at han samtidig ved sitt umiddelbare følelsesmessige engasjement gir uttrykk for at han bekrefter og verdsetter henne: «Han viser at han setter pris på meg. Jeg føler at han er en utrolig god støttespiller for meg. Det er ikke andre jeg kan snakke med på den måten». Camilla gir ham respons på en tilsvarende måte. Henrik fremhever hvordan Camilla viser at hun verdsetter og bekrefter ham. Han synes at han kan snakke mer åpent med henne enn med andre og at hun gir engasjerte tilbakemeldinger når han tar opp temaer som er viktige for ham.

Den responsivitet Henrik gir uttrykk for i samtalene med Camilla, er preget av emosjonell ekspressivitet på to måter. Han uttrykker emosjonell ekspressivitet ved å sette ord på de følelsene han har for henne og ved å formidle engasjement og interesse i samtalene med henne som gir budskap om at han bekrefter og respekterer henne. Resultatet om hvordan Henrik gir uttrykk emosjonell ekspressivitet er særlig interessant i forhold til studier som viser en tendens til at kvinner savner respons fra mannen på det emosjonelle plan (Jamieson, 1998: 146; Duncombe og Marsden, 1999: 95-97; Dempsey, 2002: 108).

Gjensidigheten i den respons begge parter gir hverandre i samtaler som er viktige for dem, gir grunnlag for en konklusjon om likeverdighet. Den responsivitet de uttrykker overfor hverandre er både basert på åpenhet om hva de føler for hverandre, og på umiddelbare reaksjoner hvor de uttrykker interesse og engasjement i forhold til hverandre. Begge føler at de blir bekreftet og verdsatt av partneren. Likeverdigheten i responsiviteten omfatter også ansvar for å ta opp problemer i parforholdet. Begge forteller at det er like ofte den ene som den andre som tar initiativ til å løse konflikter.

Den emosjonelle ekspressivitet Henrik gir uttrykk for, representerer et 
grunnlag for at mannen og kvinnen deler ansvaret for den følelsesmessige kvalitet i parforholdet. Dette er et viktig resultat i forhold til studier som fremhever at den største utfordringen for å oppnå likeverdighet i parforholdet er å utvikle et gjensidig følelsesmessig ansvar (Duncombe og Marsden, 1995: 165). Menns innsats i forhold til å ta ansvar for følelser reflekterer ifølge Jamieson (1999: 490) idealer i vår kultur som oppmuntrer menn til å være ekspressive og kommuniserende partnere.

\section{Kommunikasjon preget av lite emosjonell ekspressivitet}

Tor og Eli fremhever begge at kommunikasjonen mellom dem er den største utfordringen i parforholdet. Tor synes at han kan snakke med Eli om det meste av det han er opptatt av, og at Eli er god til å lytte, men at «kommunikasjonen lett skjærer seg», som han uttrykker det. Eli synes på sin side at det er vanskelig å snakke med Tor om tanker og følelser. Ut fra den responsen han gir, synes hun at han ikke forstår henne.

Konflikten i kommunikasjonen mellom Tor og Eli handler om at de to kommuniserer på ulike nivåer. I de beskrivelser Tor gir av samtaler med Eli om temaer de er opptatt av, fremhever han at han er orientert mot saksnivået. Han forholder seg til de hendelser hun forteller om og gir henne tilbakemeldinger i forhold til innholdet i det hun beskriver. Elis reaksjon i forhold til disse samtalene er at hun synes hun får lite respons på det som er viktig for henne. Hun savner respons fra Tor som uttrykker at han er interessert i det hun forteller, og som gir uttrykk for at han verdsetter henne.

Tor representerer et mønster som dokumenteres i flere studier hvor menn beskrives som lite emosjonelt ekspressive partnere (Dempsey, 2002: 103; Rauer og Volling, 2005: 578). Tors måte å forholde seg til samtalene på er lite emosjonelt forankret. Det betyr at han bare responderer i forhold til «saksnivået» i Elis fortelling. Han «hører ikke» de emosjonelle understrømmene, tonefallet og stemmeleiet som fremhever meningen i det hun formidler om dagens hendelser. Eli synes det er et problem at hun ikke får respons fra Tor på dette: «Han hører ordene jeg sier, men han hører ikke hva jeg mener. Han forstår ikke hva som er viktig for meg». Det er mangel på emosjonell ekspressivitet i den respons han bidrar med som er problem for henne: «Han er ikke i nærheten av å gi meg nok bekreftelse», sier hun. (Solsvik, 2004: 73-76) utdyper dette problemet når hun fremhever betydningen av at bekreftelse på følelsesmessige reaksjoner gir opplevelse av å bli anerkjent av den andre.

Konflikten i denne situasjonen handler om hva Goffman betegner som metakommunikasjon, det vil si kommunikasjon om hvilke rammer som skal gjelde i kommunikasjonen (Jacobsen og Kristiansen, 2002: 150). Tor insisterer på at saksnivået skal være den gjeldende ramme både for sin egen beretning, 
hvordan han «hører» Eli og den respons han gir henne. Eli fremhever betydningen av at rammen for samtalen både skal gjelde saksnivået og de emosjonelle undertoner som utdyper meningen i det hun formidler. Hun ønsker at Tor kan forstå hva det hun har opplevd betyr for henne.

Uenighet om rammene for kommunikasjonen gir grunnlag for en konklusjon om kjønnet makt. I de situasjonene som er beskrevet her, har mannen definisjonsmakt $\mathrm{i}$ betydningen av at han definerer at rammen for samtalen skal handle om det saklige innholdet, og ikke emosjonell ekspressivitet. Den makt Tor representerer ved å definere rammer for samtalene, har sammenheng med forskningsresultater som viser at menn tar kontroll over sine erfaringer ved å undertrykke følelser som er uforenlige med den oppfatningen de har av seg selv (Kaufman, 1994: 148-150; Seidler, 1998: 201). Duncombe og Marsden (1998: 215) hevder at en konsekvens av at menn undertrykker følelser i parforholdet, er at de på denne måten opprettholder en emosjonell avstand til sin kvinnelige partner. Når menn har mindre erfaring i å gi uttrykk for følelser, viser de også mindre interesse når andre beskriver sine følelsesmessige opplevelser, mener Duncombe og Marsden (1999: 99).

\section{Menns innsats i lys av perspektiver på likeverdighet og kjønnet makt}

Denne artikkelen tar utgangspunkt i studier som viser at kvinner savner innsats fra mannen i forhold til å ta vare på kjærligheten i parforholdet. Resultatene av analysene fremhever hvordan menn investerer i parforholdet. Mannen arbeider for kjærligheten når den omsorg han viser overfor partneren er preget av omtanke for henne. Omtanke er basert på at han reflekterer over den betydning hans innsats har for partneren og at han forsøker å bidra på måter som han oppfatter som viktige for henne.

Mannen arbeider for kjærligheten når han i kommunikasjon med partneren uttrykker en responsivitet som er preget av emosjonell ekspressivitet. En side ved en ekspressivt forankret kommunikasjon innebærer at mannen setter ord på de følelser han har for partneren. En annen side ved emosjonell ekspressivitet er at mannen i samtaler med partneren gir uttrykk for en responsivitet som formidler engasjement og interesse for henne og som gir henne en bekreftelse på å bli respektert og verdsatt.

Gjennom arbeid for kjærligheten bidrar mannen til å styrke likeverdighet i parforholdet. Konklusjonen om likeverdighet er også basert på at begge parter opplever gjensidighet i den innsats de bidrar med for kjærligheten. Gjensidigheten omfatter et felles ansvar for den omsorg de viser for hverandre, og et felles ansvar for at kommunikasjonen mellom dem innebærer en emosjonelt for- 
ankret responsivitet som bidrar til at partene føler seg bekreftet og verdsatt av hverandre.

Flere studier (Jamieson, 1998: 146-147; Haavind, 2000: 201-202) fremhever at oppfatninger av likeverd kan være basert på tendenser til at menns bidrag forstørres, mens kvinners bidrag forminskes. Resultatet av slike prosesser kan gi inntrykk av at det som oppfattes som likeverdighet er et overfladisk fenomen. Fordi vi har intervjuet partene hver for seg, har vi kunnet vurdere samstemmigheten i de beskrivelser partene gir av gjensidighet. Konklusjonene om likeverd i denne studien er basert på at begge parter gir uttrykk for gjensidighet både i omtanke for hverandre og når det gjelder emosjonelt ekspressiv responsivitet. De felles synspunkter begge parter har både når det gjelder holdninger og praksis, styrker troverdigheten av konklusjonene om likeverdighet. Den gjensidighet partene gir uttrykk for, kan beskrives med Hochschilds (2003: 105) begrep om takknemlighetens økonomi. Takknemlighet innebærer at den ene part verdsetter den andres bidrag som noe ekstra og derfor ønsker å gi noe tilsvarende tilbake.

Resultatene av denne studien viser også at mannens arbeid for kjærligheten har et mer begrenset omfang, som i situasjoner hvor hans innsats er preget av å hjelpe til fremfor å dele ansvaret med partneren. I slike situasjoner bidrar mannens innsats til å reprodusere kjønnet makt. Den kjønnede makten har referanse til "prinsippet om den minste interesse" (Engelstad, 1999: 22) Dette prinsippet innebærer at mannen investerer mindre for parforholdet enn partneren. Konsekvensen er at kvinnen har hovedansvaret for å ta vare på kjærligheten.

En annen begrensning ved mannens innsats for kjarligheten er knyttet til den type respons han uttrykker i samtaler med partneren. Han har definisjonsmakt i samtaler hvor han definerer at rammene for samtalen gjelder saksinnholdet og hvor han ikke forholder seg til en følelsesmessig utveksling. Den respons han formidler til partneren er preget av lite emosjonell ekspressivitet, og hans partner opplever at hun får lite respons på sine opplevelser og lite bekreftelse på hva hun betyr for ham.

Forholdet mellom likeverdighet og kjønnet makt er et sentralt perspektiv i mange studier av nære relasjoner. Røthing og Aarseth (2006: 176) fremhever hvordan forskning på kjønn og familie er preget av et spenningsforhold mellom perspektiver som vektlegger hvordan kjønnsarrangement reproduseres og hvordan de endres. Forskning på fedres posisjon i nye familiestrukturer fokuserer på likestillingshensyn og endringer i forholdet mellom mann og kvinne (Brandth og Kvande, 2003: 205; Lorentzen, 2006: 131). Kimmel (2004: 1-17) har utført omfattende analyser av hvordan kjønnet ulikhet og dominans produseres, reproduseres og endres i nære relasjoner som familie, vennskap og parforhold. Det budskap denne artikkelen formidler om hvordan menns inn- 


\section{sats bidrar til likeverdighet i parforhold, har relevans også i forhold til andre typer av nære relasjoner.}

\section{Referanser}

Asplund, J. (1987) Det sociala livets elementära former. Göteborg: Bokförlaget Korpen.

Beck, U. og E. Beck-Gernsheim (1995) The Normal Chaos of Love. Cambridge: Polity Press.

Bittman, M. og Lovejoy, F. (1993) 'Domestic Power: Negotiating an Unequal Division of Labour Within a Framework of Equality'. Australian and New Zealand Journal of Sociology 29:302-321.

Bourdieu, P. (1996) Symbolsk makt. Oslo: Pax Forlag.

Brandt, B. og Kvande, E. (2003) Fleksible fedre. Maskulinitet, arbeid, velferdsstat. Oslo: Universitetsforlaget.

Bråten, S. (2000) 'Altersentrisk deltagelse til grunn for at spedbarn kan gi og gjengjelde omsorg', i S. Bråten (red) Modellmakt og altersentriske spedbarn. Essays on Dialogue in Infant $\theta$ Adult (s. 71-82). Oslo: Sigma Forlag.

Bråten, S. (2004) Kommunikasjon og samspill - fra fødsel til alderdom. Oslo: Universitetsforlaget.

Cohen, D. (1990) Being a man. London: Routledge.

Dempsey, K. (2002) 'Who gets the best deal from marriage: women or men?'. Journal of Sociology, 38:91110.

Duncombe, J. og Marsden, D. (1995) 'Workaholics' and 'whingeing women': Theorising intimacy and emotion work - the last frontier of gender inequality?'. The Sociological Review 43:150-169.

Duncombe, J. og Marsden, D. (1998) 'Stepford wives' and 'hollow men'. Doing emotion work, doing gender and 'authenticity' in intimate heterosexual relationships', i G. Bendelow og S. J. Williams (red) Emotions in Social Life. Critical Themes and Contemporary Issues (s. 211-227). London: Routledge.

Duncombe, J. og Marsden, D. (1999) 'Love and Intimacy: The Gender Division of Emotion and 'Emotion Work': A Neglected Aspect of Sociological Discussion and Heterosexual Relationships', i G. Allan (red) The Sociology of the Family (s. 91-110). Oxford: Blackwell Publishers.

Engelstad, F. (1999) 'Maktbegrepet etter Max Weber', i
F. Engelstad (red) Om makt. Teori og kritikk (s. 1542). Oslo: Gyldendal Norsk Forlag.

Giddens, A. (1994) Intimitetens forandring. Seksualitet, kxrlighet og erotik $i$ det moderne samfund. København: Hans Reitzels Forlag.

Goffman, E. (1974) Frame Analysis. An Essay on the Organization of Experience. Boston: Northeastern University Press.

Gross, N. (2005) 'The Detraditionalization of Intimacy Reconsidered'. Sociological Theory 23: 286-311.

Gross, N. og Simmons, S. (2002) 'Intimacy as a Double-Edged Phenomenon? An Empirical Test of Giddens'. Social Forces 81:531-555.

Haavind, H. (2000) 'Analytiske retningslinjer ved empiriske studier av kjønnede betydninger', i $\mathrm{H}$. Haavind (red) Kjønn og fortolkende metode. Metodiske muligheter i kvalitativ forskning (s. 155-219). Oslo: Gyldendal Norsk Forlag.

Hochschild, A. R. (2003) The Commercialization of Intimate Life. Notes from Home and Work. Los Angeles: University of California Press.

Holmberg, C. (1995) Det kallas kärlek. Om kvinneligt och manligt. Maktförhällandet $i$ parrelationer. Göteborg: Anamma Förlag.

Holmes, M. (2004) 'An equal distance? Individualization, gender and intimacy in distance relationships'. The Sociological Review 52:180-200.

Holter, Ø. G. (1995) 'Family Theory Reconsidered', i T. Borchgrevink og Ø. G. Holter (red) Labour of Love. Beyond the self-evidence of everyday life (s. 99-130). Aldershot: Avebury.

Illouz, E. (1997) Consuming the Romantic Utopia. Love and the Cultural Contradictions of Capitalism. Los Angeles: University of California Press.

Jacobsen, M. H. og Kristiansen, S. (2002) Erving Goffman. Sociologien om det elementxre livs sociale former. København: Hans Reitzels Forlag.

Jamieson, L. (1998) Intimacy. Personal Relationships in Modern Societies. Cambridge: Polity Press. 
Jamieson, L. (1999) 'Intimacy Transformed? A Critical Look at the 'Pure Relationship' Sociology 33477 494.

Jónasdottir, A. G. (1991) Love, Power and Political Interests: Towards a Theory of Patriarchy in a Welfare Society. Örebro: University of Örebro.

Kaufman, M. (1994) 'Men, Feminism, and Men's Contradictory Experiences of Power', i H. Brod og M. Kaufman (red) Theorizing Masculinities (s. 142163). London: Sage Publications.

Kimmel, M. S. (2004) The Gendered Society. Oxford: Oxford University Press.

Lorentzen, J. (2006) 'Forskning på menn og maskuliniteter', i J. Lorentzen og W. Mühleisen (red) Kjønnsforskning. En grunnbok (s. 121-135). Oslo: Universitetsforlaget.

Rauer, A. J. og Volling, B. L. (2005) 'The Role of Husbands' and Wives' Emotional Expressivity in the Marital Relationship' Sex Roles 52:577-587.

Røthing, Å. (2004) Parforhold. Idealer, forhandlinger, strategier. Oslo: Gyldendal Norsk Forlag.

Røthing, Å. og Aarseth, H. (2006) 'Kjønn og familie', i J. Lorentzen og W. Mühleisen (red) Kjønnsforskning. En grunnbok (s. 169-177). Oslo: Universitetsforlaget.
Seidler, V. (1998) 'Masculinity, violence and emotional life', i G. Bendelow og S. J. Williams (red) Emotions in Social Life. Critical Themes and Contemporary Issues (s. 193-210). London: Routledge.

Skatvedt, A. (2006) 'Det vakre i det alminnelige' Sosiologi $i$ dag 36:37-58.

Solsvik, A. (2004) 'Likeverd i barneoppdragelsen', i I. Frønes og T.S. Wetlesen (red) Dialog, selv og samfunn (s. 61-86). Oslo: Abstrakt Forlag.

Strazdins, L. og Broom, D. H. (2004) 'Acts of Love (and Work). Gender Imbalance in Emotional Work and Women's Psychological Distress'. Journal of Family Issues 25:356-378.

Thagaard, T. (2005) Følelser og fornuft. Kjxrlighetens sosiologi. Oslo: Abstrakt Forlag.

Thompson, L. og Walker, A. (1989) 'Gender in families: women and men in marriage, work and parenthood' Journal of Marriage and the Family 51:845871 .

Wærness, K. (1999) 'Omsorgsetikk og politisk diskurs', i G. E. Birkelund, A. K. Broch-Due og A. Nilsen (red) Ansvar $\theta$ protest. Kjønn, klasse og utdanning $i$ senmoderniteten (s. 103-116). Bergen: Sosiologisk institutt, Universitetet i Bergen. 